\title{
圧延における表面疵変形過程の予測
}

\author{
石川孝司 *
}

\section{Prediction of Deformation of Surface Micro-Defects in Rolling}

\author{
Takashi Ishikawa
}

\section{Synopsis}

Surface micro-defects affect surface quality and cause breakdown and cracks in rolled products. Many efforts have been made to prevent the occurrence of micro-defects in rolling plants, however, producing defect-free products remains very difficult. Many kinds of surface defects occur in rolling processes. The shapes of surface defects after rolling change in various manners, depending on the rolling conditions. Determining the relation between the shape of surface defect before rolling and that after rolling may lead to an effective method for predicting the occurrence of a surface defect and development of a process to eliminate defects. This review is focus on the numerical approach to predict surface microdefects in rolling.

\section{1. 緒言}

圧延製品の表面には種々の形状の疪が現れる場合があ る .これらの疵は鋼材の品質を損ない 2 次加工時に割れな どの重大な欠陥を引き起こすばかりでなく，製品の製造過 程においても，材料の破断や割れを引き起こす原因にもな り，効率的な圧延作業の妨げとなるため，作業現場では疵 を発生させないよう非常な努力がなされている ${ }^{1,2)}$. たと えば,製鋼段階で㠜固シェルの安定化，モールドパウダー の巻き込み防止，連鋳スラブのスカーフィングの徹底，ス ケールの安定化, デスケール技術の工夫 , 圧延時の異物巻 き込み防止など各工程で取組がなされている.また，古く から表面疪に関する研究も多い，しかし，現段階では疵を 発見してから光の場しのぎの対策をとるのが一般的であ り，しかも光の疵を見て原因を同定できない場合も多く， 疵の発生を完全に防止することは困難な状況にある．

圧延製品に発生する疪の形状は発生要因などにより 種々であり，発生後に幾重にも圧延加工が施されること で，圧延後の疵はさまざまな形状を呈することになる．こ のことは圧延後の疵形状と圧延前の疵形状を正確に対応 づけられることができれば, 疪の発生原因の有効な推定手
段となり，疵を減少させるための対応策もとることができ ることを示している.このような観点から，これまでにも 鋼スラブ表面に機械加工で人工疵を施して圧延実験をし て疵の変形を調査した例もある ${ }^{3)}$ ） ${ }^{2)}$. 時間と経費のかか る実験ではなく，数值シミュレーションで疵の予測が可能 となれば非常に有効である.しかし，数值解析を用いた表 面疪の变形に関する研究はほとんどない，乥れは疵部が材 料全体の体積に比して微小であるので,ママクロ変形と同時 に局部的なミクロ領域の変形を非定常で解析する必要が あるためである この圧延疪に対する数值解析手法の開発 を目的に, 2000 年 4 月より(社) 日本鉄鋼協会の中で「表 面疪発生過程予測技術の開発」研究会が発足, 活動し基礎 的な成果が得られている9).

ここでは，圧延疵に関係する従来の研究を概説したあ と, 光の研究会での成果をもとに板圧延における圧延疵 の変形メカニズムについて解説する

\section{2 . 圧延疵}

\section{1 圧延疪の種類}

圧延時に生ずる表面疪の種類は多種あり，系統的に整理 されているものではないが，下記に板圧延における代表的 
なものを挙げる $\left(\right.$ Table $1^{2)}$ ) .

スケール疵 : 表面にスケールが圧着またはかみ込んだも の.赤スケール, あばた状スケール, 線状スケール, 点状 スケールなどさまざまな形態がある .

へげ (Scab) : 表面が录がれやすいラップ状の疵 .

スリバー (Sliver) : 圧延方向に断続的に出る比較的浅い線 状疪 .

シーム (Seam) : 圧延方向に平行な線状の疵.

ガウジ (Gouge) : 核があり，板表面にくぼみがある .

形態が同じでも原因が異なるものもあるともいわれてお り，発生メカニズムは諸説あり，不明なものも多い.Fig.1 は考えられる疵の原因を図示したもので, 上流側から CC 鋼塊製造時の表面不良，割れ，表面層中の不純物，介在 物, ブローホール, 加熱炉から粗圧延, 熱延入口までのか き疵, すり疵, 圧延中のロール疵, スケール巻き込み, 異 物飛込みなどである。

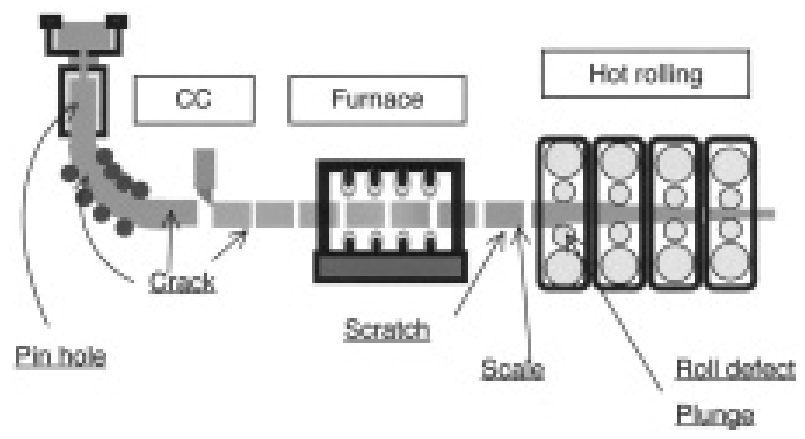

Fig.1. Affectors on surface micro-defects in steel making.

\section{2 従来の研究}

これまでにいろいろな観点から疵の発生原因や進展メ カニズム, 疵防止法について報告されているが , ここでは 圧延時の疪の変形についての報告例を紹介する .Table 1 に 示した各種の疵の原因について西島 ${ }^{10)}$ は, 以下の 10 項目 に分類している．

1) 鋼塊に存在した内外欠陥から生じるもの.

2) 加熱が不適当なために生じるもの.

3) 圧延温度が不適当なため生じるもの.

4) 圧延の時機械的原因によって生じるもの.

5) 非金属介在物によって生じるもの.

6) 鋼材表面における濃化元素によって生じるもの .

7) 酸洗ぜい化が影響して生じるもの.

8) 鋼の材質不良によって生じるもの.

9) 疵取り方法, あるいは炎の手法に原因するもの.

10) 鋼材の運搬工程中の疵, 炎の他人為的なもの.

Table $2^{3)}$ は中炭素 $\mathrm{Al}$ キルド鋼のスラブを対象として , ノロカミ (Slag spot), タテワレ (Longitudinal crack) , ヨコ ワレ (Lateral crack) などの代表的な表面欠陥疵を残したま ま熱間圧延をした後，コイルの表面を観察した結果であ る.ノロカミとタテワレは線状の疵に, ヨコワレはへげ状 疵になり，内部にスケールが観察された .

Fig. ${ }^{5)}$ は $80 \mathrm{~mm}$ 厚の鋼片に幅 $1 \mathrm{~mm}$ で深さの異なる (B: $15 \mathrm{~mm}, \mathrm{D}: 5 \mathrm{~mm}$ ) 矩形状の溝を人工的に施し，1473 K で 圧延した後の溝の変化を示したものである . 図中の $3,4,5$ は大気雰囲気の加熱で，8, 9, 10 はスケールを防止した加 熱条件である . 浅い疵の場合は圧延とともに開口が生じ，

Table 1. Classification of micro defects on rolled plate ${ }^{2)}$.
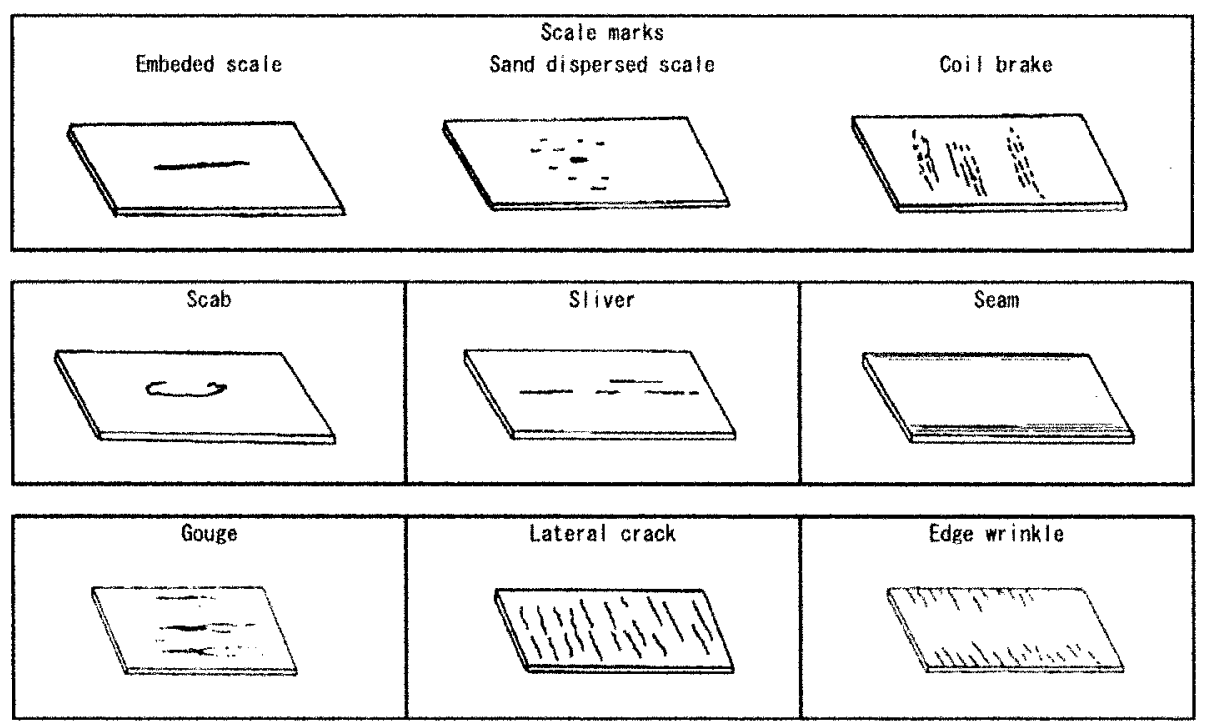
Table 2. Aspect of slab surface defect and hot coil surface defect ${ }^{3)}$.

\begin{tabular}{|c|c|c|c|c|c|}
\hline \multicolumn{2}{|c|}{ Slab } & \multicolumn{4}{|c|}{ Hot coil } \\
\hline \multirow{2}{*}{$\begin{array}{l}\text { Name of } \\
\text { defect }\end{array}$} & \multirow[b]{2}{*}{ Sketch } & \multicolumn{3}{|c|}{ Aspect of defect } & \multirow[b]{2}{*}{ Feature of defect } \\
\hline & & Name & $\begin{array}{l}\text { Surface } \\
\text { sketch }\end{array}$ & $\begin{array}{l}\text { Section } \\
\text { sketch }\end{array}$ & \\
\hline Slag spot & 4 & Sliver & & $\frac{10 \mu m}{L_{000}}$ & $\begin{array}{l}\text { Existing inclusions on } \\
\text { surface or in sub- } \\
\text { surface }\end{array}$ \\
\hline $\begin{array}{l}\text { Longitudinal } \\
\text { crack }\end{array}$ & & Sliver & & $\frac{20 \mu m}{1 \text {-pitmm }}$ & $\begin{array}{l}\text { Existing large scales } \\
\text { which contain grained } \\
\text { oxide }\end{array}$ \\
\hline $\begin{array}{l}\text { Lateral } \\
\text { crack }\end{array}$ & & Scab & & $\frac{100 \mu m}{T}$ & Same \\
\hline
\end{tabular}
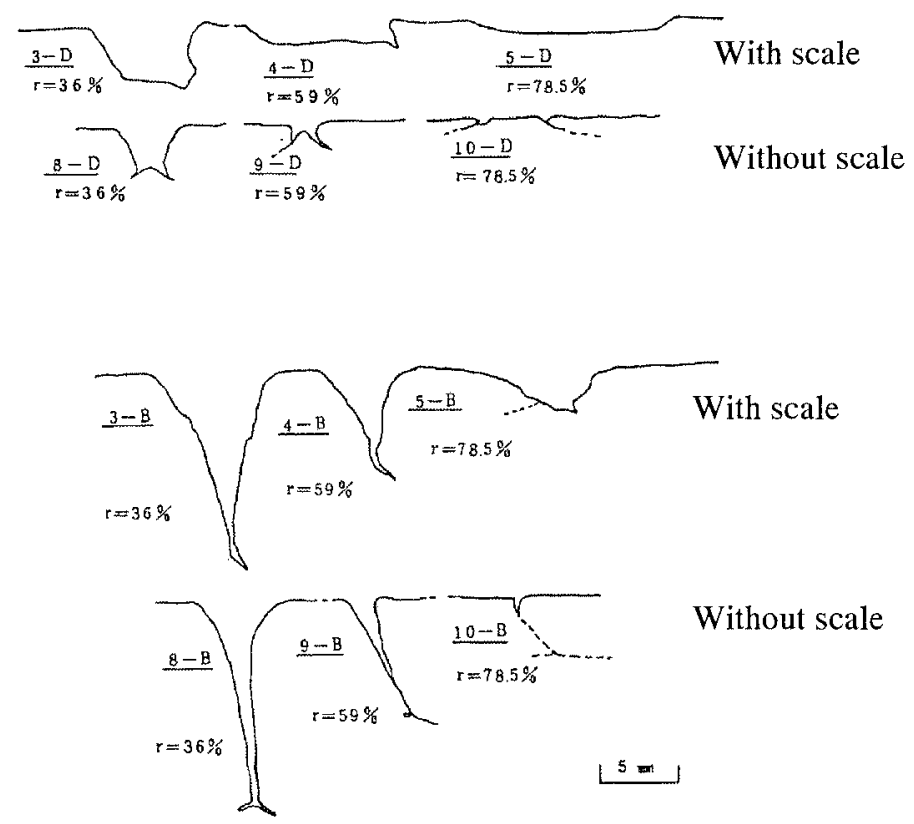

Fig.2. Deformation of micro-defects in plate rolling ${ }^{5)}$.

広く浅いくぼみになるが, 条件によっては溝の底部が盛り 上がってハの字を呈する.また，深い溝の場合は底部が接 触し鍛着現象がみられ，先端にスケールの影響とみられる 粒状酸化物の点在が観察された .また，加熱スケールの状 態によっても変形が異なることが明らかである．
冷延鋼板で問題となるスリバー疪は，表層近傍のピン ホールや連鋳時のモールドパウダーの巻き込みなどが原 因で, 乥れが圧延により表面に現れ，表面疪となると考え られている . 井上ら ${ }^{7)}$ は , アルゴンガスやアルミナを封 入した人工欠陥を内部に導入して圧延実験を行い,アルゴ 
ンガスを封入した場合には圧下率 $85 \%$ で消滅するが，ア ルミナを封入した場合には $96 \%$ で線状に変形し，表面に 開口することを示した . 福島ら ${ }^{11)}$ は，同樣な実験により 初期内部欠陥の深さと大きさの影響を調査している (Fig.3) . アルミナを封入した人工欠陥は, 疪になること を確認し，初期に大きなものほど深い位置にあっても疪に なることを示した 。

シーム疪は圧延中に側面部に発生したしわ (表面の凹 凸）が, 板表面にフォールディングで回り込み, 圧延方向 に線状の疪となって残るもので,初期に欠陥がなくても疵 が発生する．側表面の結晶粒の方位の影響 ${ }^{12)}$, 回り込み 変形量の検討 ${ }^{13)}$ などが行われている.

フェライト系ステンレス鋼の冷間圧延時に現れる白筋 模樣と呼ばれる疵 (Fig.4) は，表面研削することによっ て表面加工層 (Fig.4(a)) の延性が低下し，流体潤滑によ り表面層に働く付加的引張応力により，圧延中に圧延方向 と直角方向に亀裂か現れ (Fig.4(b)), 圧延とともに拡大す る (Fig.4(c)) との報告 ${ }^{14)}$ がある.

Fig.5 はゴールドダスト疪（鱗状かぶさり疵）と呼ばれ るもので,表面の材料の一部か薄片となってか心゙さってい る欠陥である .これは，初期の表面粗さか関係しており， 表面の凹凸がFig.6のような変形をするために発生すると 報告 ${ }^{15)}$ されている .
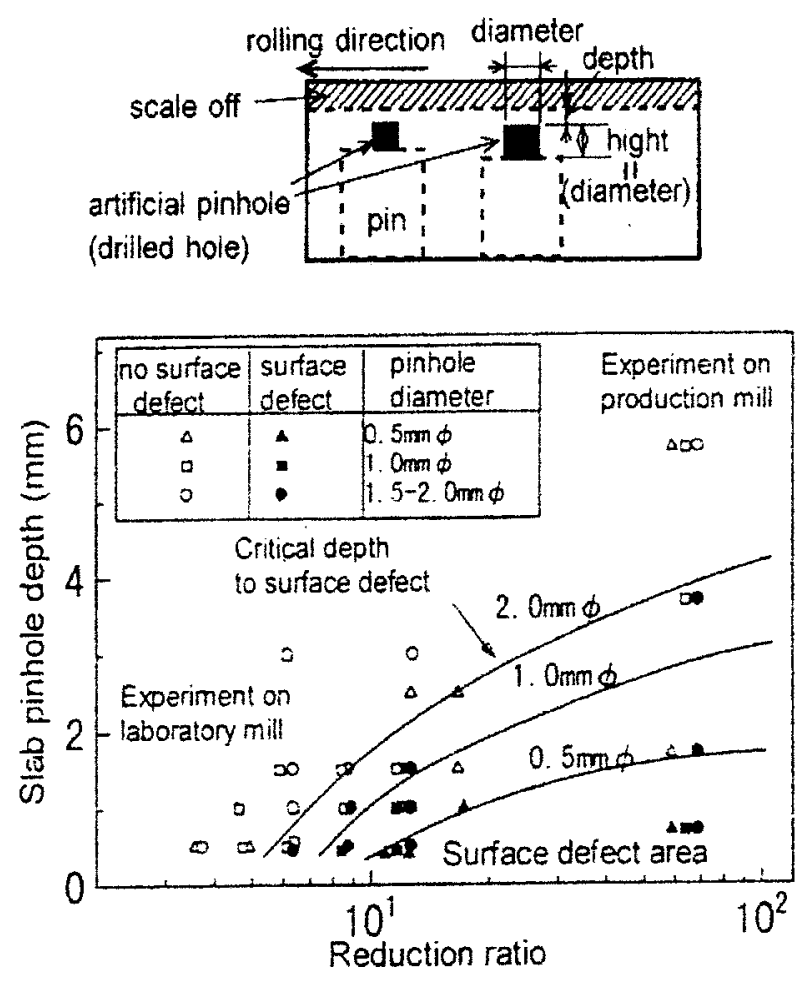

Fig.3. Critical depth to surface defect ${ }^{11)}$.
スケールは,一般に延性がなく, 圧延中に破懐, 剥離を 起こし，さらに剥離したスケールが異物としてかみ込まれ るなど，さまざまな表面欠陥の原因となる . 小野田ら ${ }^{16)}$ は,各種のスケール疵の形態と原因について説明している ので参考にされたい . Fig.7 は, うろこ状スケール疵の発 生メカニズムを定性的に説明したもので,スタンド間で発 生する二次スケールが, 体積変化により剥離し盛り上がっ てブリスタリングを起こし, 鋼板表面に疵を発生させると 説明されている ${ }^{17)}$.

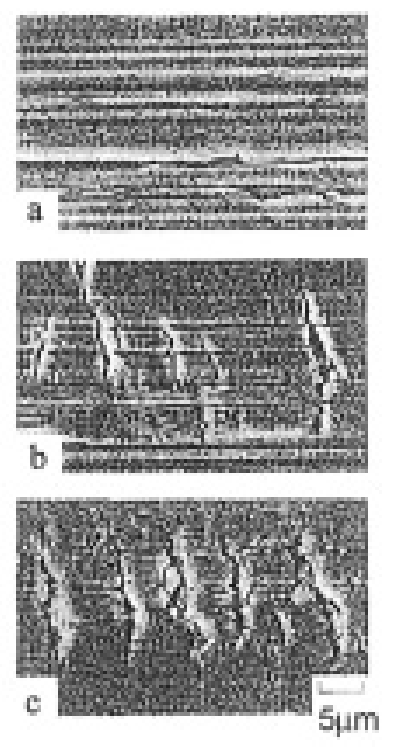

Fig.4. SEM of SUS430 sheet through GR process ( a: as ground, $\mathrm{b}$ : as cold rolled at first pass, c: as cold rolled at final pass $)^{14)}$.

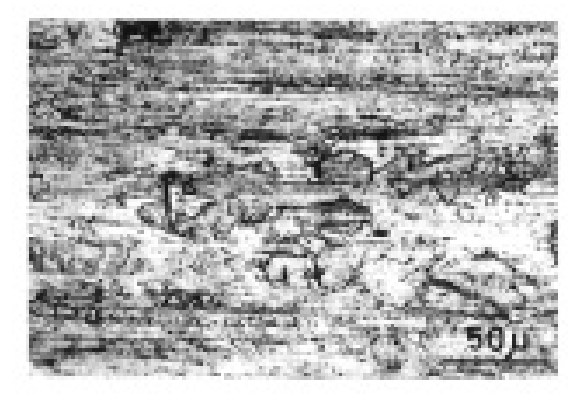

Fig.5. Optical micrograph of cold rolled surface of steel sheet with roughness of $46 \mu \mathrm{m}$ after annealing and pickling ${ }^{15)}$.
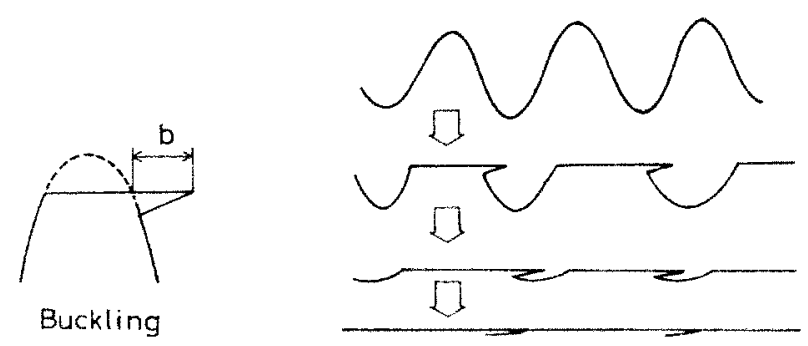

Fig.6. Schematic diagram of deformation at tip of uneven surface ${ }^{15)}$. 


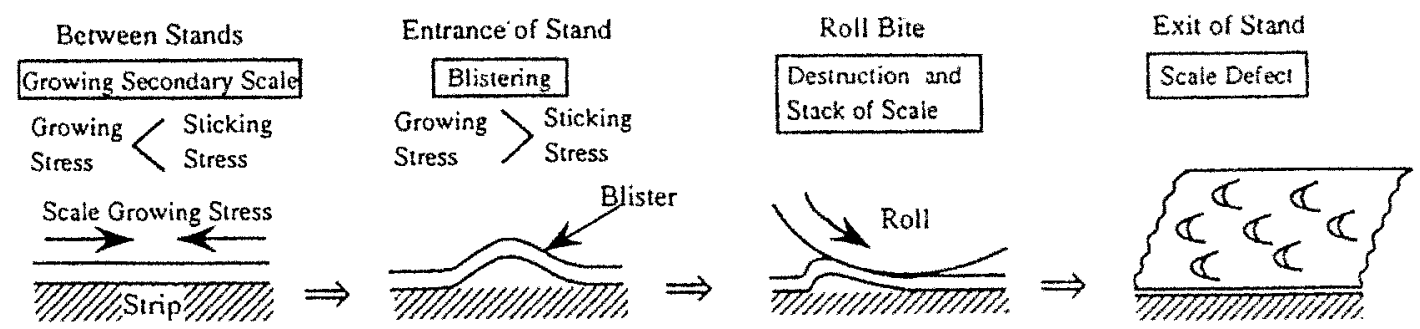

Fig.7. Mechanism of secondary scale defect ${ }^{17)}$.

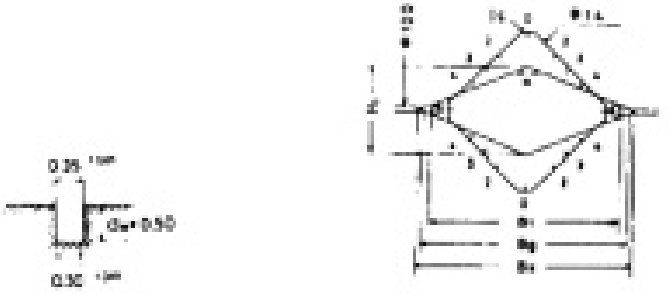

Initial defect Position at Square-diamond pass

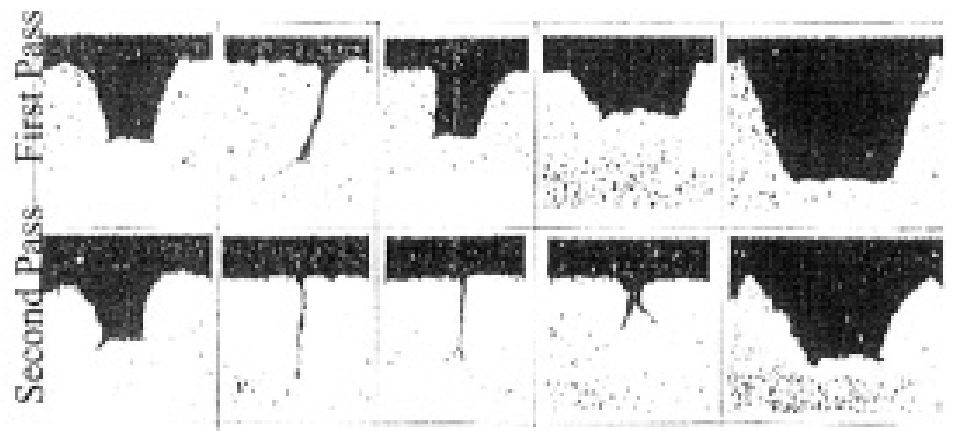

$(0)$

(2)

(3)

(4)

(6)

Fig.8. Deformed shape of artificial defects on bar rolling ${ }^{18)}$.

Fig.8は, 熱間孔型圧延での表面疪の変形を人工疵によ る実験で確認した結果である ${ }^{18)}$. 孔型圧延でも Fig.2 と同 樣な変形をするが, 断面内での変形の不均一が大きいの で, 素材断面の場所によって変形状態は大きく異なる.場 所により, 疵が開口する位置，閉じてラップ状になる位 置, 疵深さが浅くなる位置がある.このため, 角 - ダイヤ - 角 ,あるいは角 -オーバル - 角などの各パスでの孔型設 計により，疵の低減が可能であることが示されている．

以上のように各種の疵低減のための研究, 努力がなされ てきたが，いまだに表面無欠陥の製造技術が完成している とはいい難い .これまでの技術に数值解析を加えることに より,さらに進んだ表面品質の造り込み技術が開発される

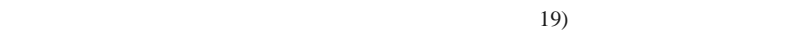

\section{3. 解 析}

\section{1 解析方法}

著者らの研究室で開発している剛塑性有限要素解析ソ フト RIPAD - 2D は ,メッシュサイズの設定などが自由に コントロールできるため, 局部変形解析など , 微小領域の 解析が可能である .

疵は板の上面に圧延方向に対して $90^{\circ}$ にあるものとし， 平面ひずみ問題として解析した .解析に使用したメッシュ の一例をFig.9 に示す . 疪近傍に段階的に細かなメッシュ をつくることで疵付近の変形を詳細に表現できるように した .解析上は上下対称であるとみなして板の上半分のみ を解析対象とした . 


\section{2 解析条件}

解析条件は, (1) 解析精度検証のためにアルミニウムの モデル実験と同条件と，(2) 低炭素鋼の熱間粗圧延段階を 想定して，各種圧延条件の影響を解析的に検討するための 条件を設定した 解析に用いた圧延条件をTable 3 に示す． 圧下スケジュールの影響をみるために Table 4 に示す 2 種 類のスケジュールで行った . また , パスは一方向圧延とし た .ただし，摩擦係数 $\mu=0.20$, ロール半径 $R=100 \mathrm{~mm}$ を標準の圧延条件とする．

\section{3 対象とした疵形状}

ここでは 4 種類の疵・突起形状を解析対象とした . 光れ らの外形と疵・突起の概要を Fig.10 に示す.ここでは鋼 板に存在する，凹状にへこんだ欠陥に対し「疵」と呼び， 製鋼時から残留したへこみ疵，圧延過程での引つ掻き疵や スケールがはがれ落ちたくぼみ,あるいは異物飛び込みに

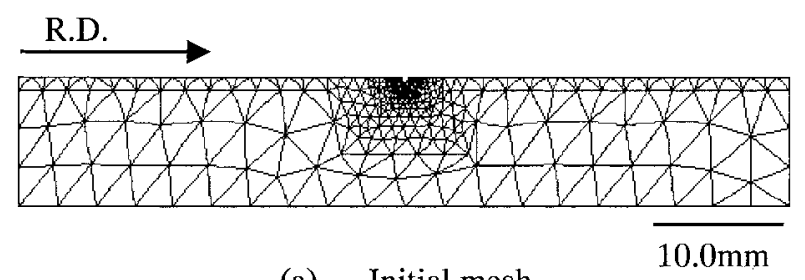

(a) Initial mesh

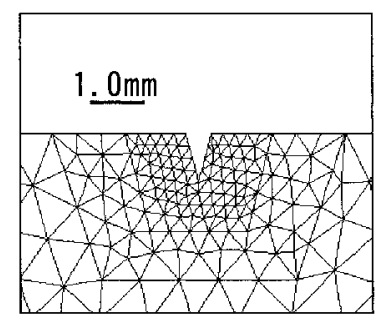

(b) Mesh around defect
より表面がへ込んだ疵などを想定した .また，凸状つまり 鋼板表面より突出した欠陥に対しては「突起」と表現し， 圧延過程でロール表面異常が材料に転写された場合や異

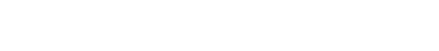

\section{4 . 解析結果及び考察}

\section{1 実験結果との比較}

Table 5 に実験に用いたアルミニウムA 1050 の変形抵抗 と, 圧延機の主な仕樣について示す．圧延方向に対して 90 方向に $\mathrm{V}$ 字疪を直線状につけ, 兴の深さ $d=0.5 \mathrm{~mm}$ 一定とし開口部の幅 $\mathrm{w}$, 角度 $\mathrm{a}$ を変化させた (Table 6) . また, 圧下率は 20/1，30/2，40/3，65/4\%/pass として段階 的に圧延した . 実験温度は $293 \pm 1 \mathrm{~K}$, 潤滑は無潤滑であ る.圧延後, 光学顕微鏡を用いて試験片中央部の疪の深さ と開口部の幅を測定した .

実験結果と同条件で行った解析結果を比較して Fig.11

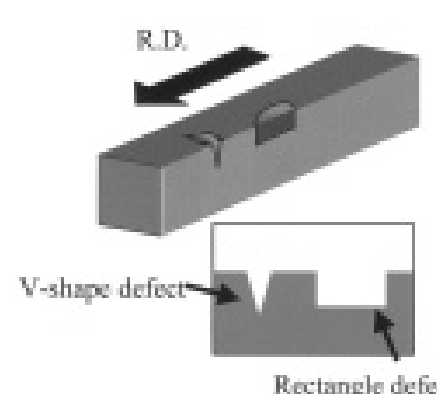

(a) Hollow defoct

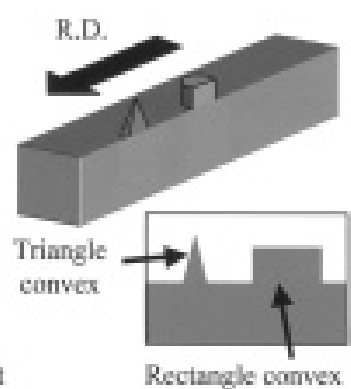

(b) Convex defect
Fig.10. Schematic figure of surface defect ${ }^{19}$.

Fig.9. Example of mesh ${ }^{19)}$.

Table 3. Rolling condition.

\begin{tabular}{l|c}
\hline Rolling temperature & $1473 \mathrm{~K}$ \\
\hline Roll rotational speed & $0.400 \mathrm{rpm}$. \\
\hline Roll radius & $R=60,100,200 \mathrm{~mm}$ \\
\hline Friction coefficient & $\mu=0.20,0.35,0.50$ \\
\hline
\end{tabular}

Table 4. Pass schedule.

\begin{tabular}{l|c|c|c|c}
\hline & \multicolumn{2}{|c|}{ Series 1 } & \multicolumn{2}{c}{ Series 2 } \\
\hline & $t(\mathrm{~mm})$ & $\varphi(\%)$ & $t(\mathrm{~mm})$ & $\varphi(\%)$ \\
\hline Initial & 20.0 & 0 & 20.0 & 0 \\
\hline 1st pass & 14.0 & 30 & 10.0 & 50 \\
\hline 2nd pass & 10.0 & 30 & - & - \\
\hline
\end{tabular}

$t$ : Plate thickness, $\varphi$ : Total rolling reduction 
Table 5. Rolling condition.

\begin{tabular}{l|c}
\hline Material & Aluminum A1050-O (JIS) \\
\hline F-value & $112 \mathrm{MPa}$ \\
\hline $\mathrm{n}$-value & 0.18 \\
\hline Thickness & $10 \mathrm{~mm}$ \\
\hline Length & $150 \mathrm{~mm}$ \\
\hline Width & $47 \mathrm{~mm}$ \\
\hline Roll radius & $100 \mathrm{~mm}$ \\
\hline Roll length & $250 \mathrm{~mm}$ \\
\hline Roll material & $500 \mathrm{~N}$ \\
\hline Maximum load & $0.395 \mathrm{rpm}$. \\
\hline Rolling velocity & High carbon bearing chrome steel \\
\hline
\end{tabular}

Table 6. Initial dimension of V-shape defect.
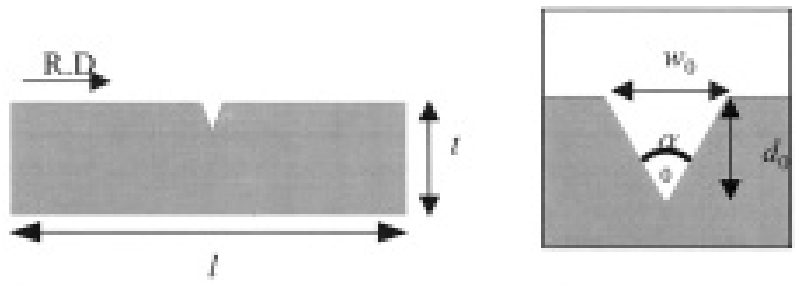

\begin{tabular}{|c|c|c|}
\hline Defect width : $w_{0}$ & $0.27 \mathrm{~mm}$ & $1.50 \mathrm{~mm}$ \\
\hline Defect depth $: d_{0}$ & $0.5 \mathrm{~mm}$ & $0.5 \mathrm{~mm}$ \\
\hline Defect tip angle : $a_{0}$ & $30^{\circ}$ & $112^{\circ}$ \\
\hline
\end{tabular}

Experimem
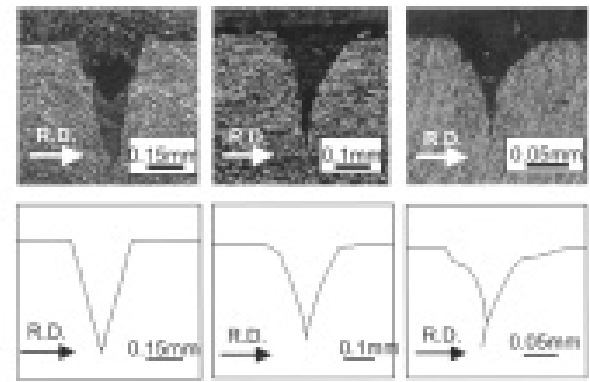

Thicknes:

$10.0 \mathrm{~mm}(0 \mathrm{~ns})$

s. 0 anm $(20)$

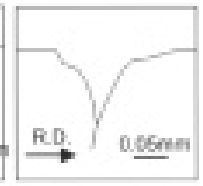

6 inmu $(4 i \mathrm{i} / \mathrm{s})$

CTotal rolline noductine

Fig.11. Comparison between experimental and analytical result $\left.\left(a_{0}=30^{\circ}\right)^{19}\right)$

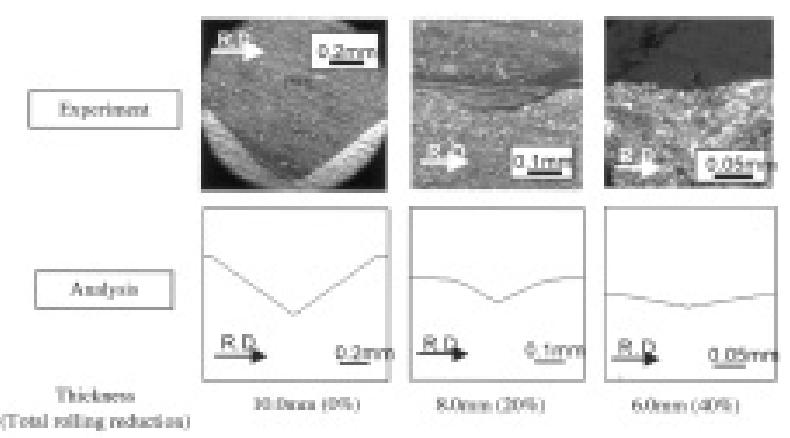

Fig.12. Comparison between experimental and analytical result $\left(a_{0}=112^{\circ}\right)^{19}$ ).
およびFig.12 に示す. 摩擦係数は $\mu=0.20$ とした .

$\mathrm{w}_{0}=0.27 \mathrm{~mm}$ の疵の圧延後の断面形状は, 圧下率の増 加とともに V 字形状疵の両斜面が盛り上り，疵底部から 閉じていく.また， $\mathrm{w}_{0}=1.50 \mathrm{~mm}$ の場合の断面形状は，圧 下率の増加とともに V 字形状疪が全体的に小さくなって いく.いずれも実験結果と良く一致している.

以上より,本解析によって表面疪の形状変化を予測する ことが可能であると考えられる.次に本解析により，各種 疵形状の変形に及ぼす圧延条件の影響を検討する。

\subsection{V 字形状疵}

初期 $\mathrm{V}$ 字形状疵の圧延による变化を解析した．摩擦係 数, ロール半径, 圧下スケジュールの表面疪変形に及ぼす 影響を調査した。

(a) 1 パスでの疵形状変化

初期疵開口部 $0.3 \mathrm{~mm}$, 初期疵深さ $1.0 \mathrm{~mm}$, 圧下率 $30 \%$ の解析結果を Fig.13 に示す．V 字形状疵はロールにかみ 込まれる際, 若干 V 字が開くが, 弚のまま V 字の形を残 して圧延され，圧延が進行することで疵の $\mathrm{V}$ 字の底部か ら圧着を起こすことが確認できる．

(b) 摩擦係数の影響

圧延による V 字形状疵の変化におよぼす摩擦係数の影 


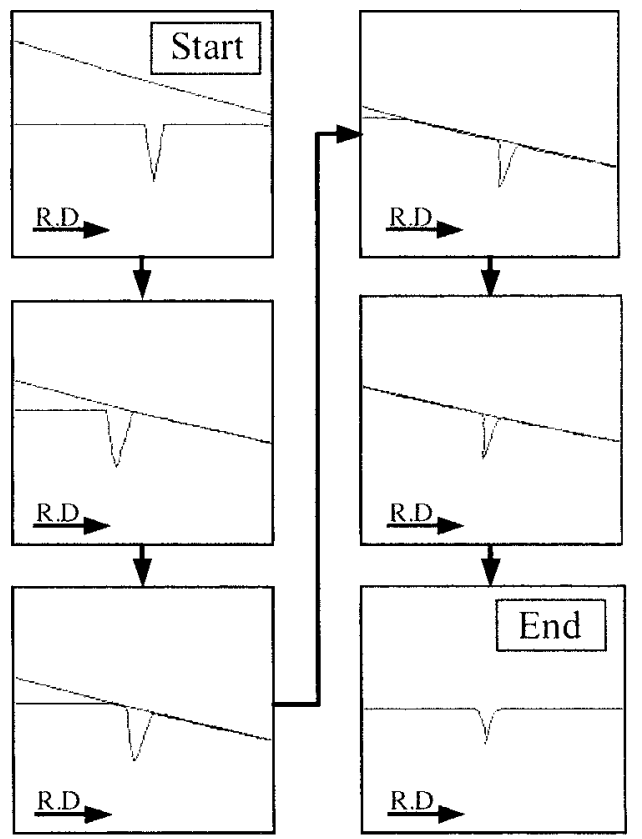

Fig.13. Example of deformation of $\mathrm{V}$-shape defect ${ }^{19}$ ). (thickness $t$ $=20 \mathrm{~mm}$, rolling reduction $\varphi=30 \%, \mu=0.20$ )

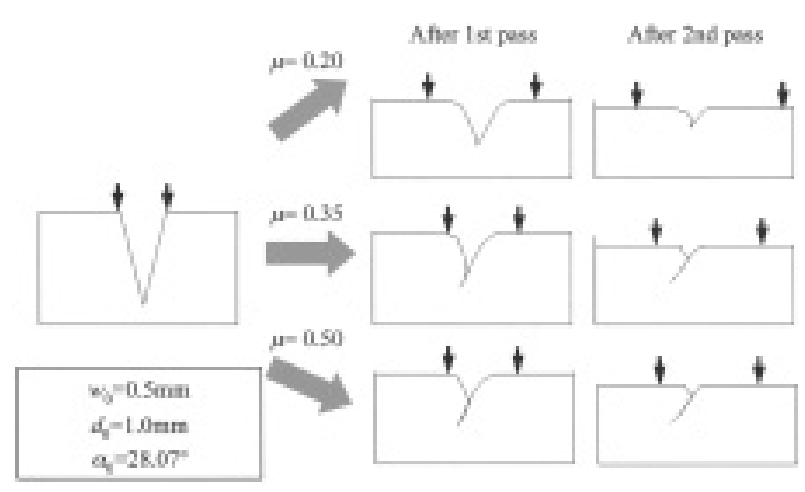

Fig.14. Influence of friction on V-shape defect after rolling ${ }^{19)}$. (thickness $t=20 \mathrm{~mm}$, rolling reduction $\varphi=30 \rightarrow 50 \%$ )

響をFig. 14に示す.初期疵開口部長さ $\mathrm{w}_{0}$ は $0.5 \mathrm{~mm}$ とした .

摩擦係数が高いほど疵開口部が狭くなる傾向が見られ る.疪深さは摩擦係数が大きいほど浅くなり, 圧着部長さ は長くなっている.すなわち, 高摩擦条件ほど疪が閉じる ことがわかる .

(c) 圧下スケジュールの影響

Fig.15 は，Table 4 に示した圧下スケジュールでの疵形 状変化である.摩擦係数 $\mu=0.20$, 初期疵開口部長さは $0.5 \mathrm{~mm}$ である。

圧延後の疵開口部長さおよび深さともに Series2 の方が 小さくなる.この条件では圧着は見られなかった .高圧下 が庛を消失させるのに有効であることがわかる .1 パスで の圧下量が大きい圧延では,かみ込み角度が大きいことか ら材料かみ込み時に圧延材を大きく変形させる.乥のため

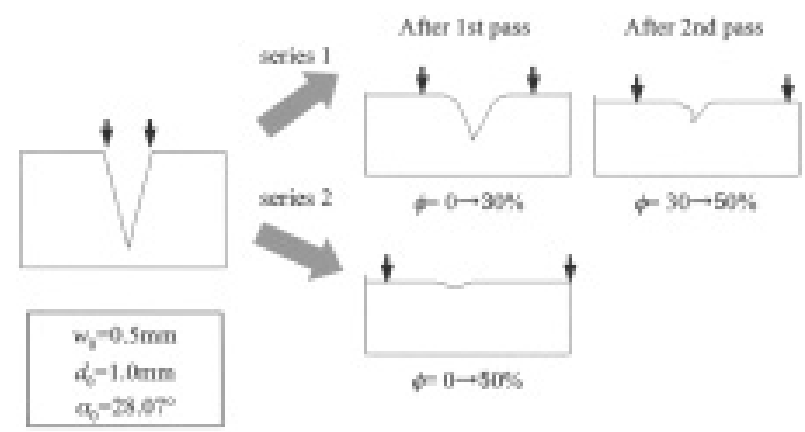

Fig.15. Influence of pass schedule on V-shape defect after rolling ${ }^{19)}$. (thickness $t=20 \mathrm{~mm}, \mu=0.20$ )

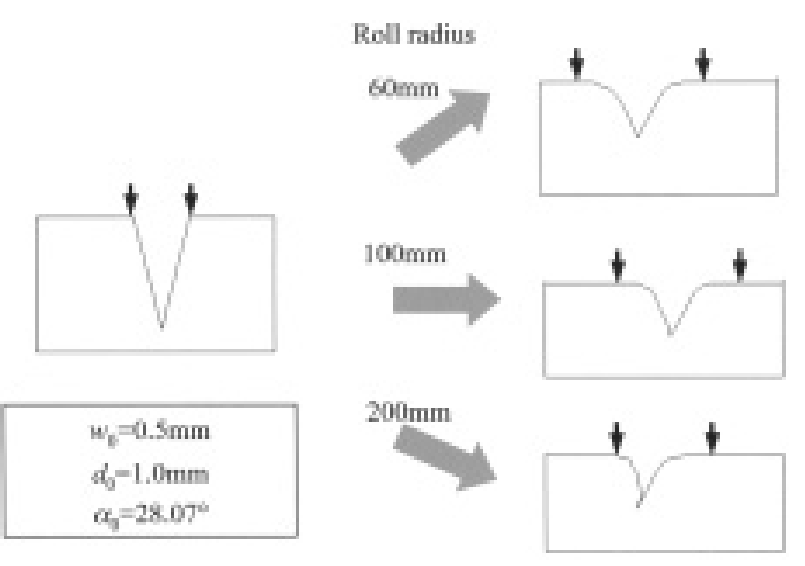

Fig.16. Influence of roll radius on $\mathrm{V}$-shape defect after rolling ${ }^{19)}$. (thickness $t=20 \mathrm{~mm}$, rolling reduction $\varphi=0 \rightarrow 30 \%, \mu=0.20$ )

圧下量が大きい圧延では, 疵部がロールにかみ込まれる際 にV字がより大きく開くと考えられる .

(d) ロール径の影響

ロール径の影響をFig.16 に示す．ロール径が大きいほ ど庛底部で圧着がおこり, 結果的に疪深さは小さくなる傾 向がみられる。

\section{3 矩形状凹形疪}

矩形状凹形疪が圧延によってどのように変形するかを 調査した 疵開口部長さ $\mathrm{w}_{0}$ は $2.0 \mathrm{~mm}$, 疵深さ $d_{0}$ は $1.0 \mathrm{~mm}$ とした。

圧下率 $30 \%$ の解析結果を Fig.17 に示す.矩形状凹形疵 はロールにかみこまれていくと圧延方向前方の壁面が鋼 板表面に露出した状態になり，壁面の下方で若干の倒れこ みがおこり小さな疪として残る.疪の後方壁面は圧延によ り前方へと倒れこみ, 相対的に盛り上がってくる凹状欠陥 の底部と接触し，大きな疪として残る．弚の結果，「八の 字型」の疵が残ることになる．

\section{4 三角形状突起}

ここでは三角形状の突起,つまり先端がとがった突出物 


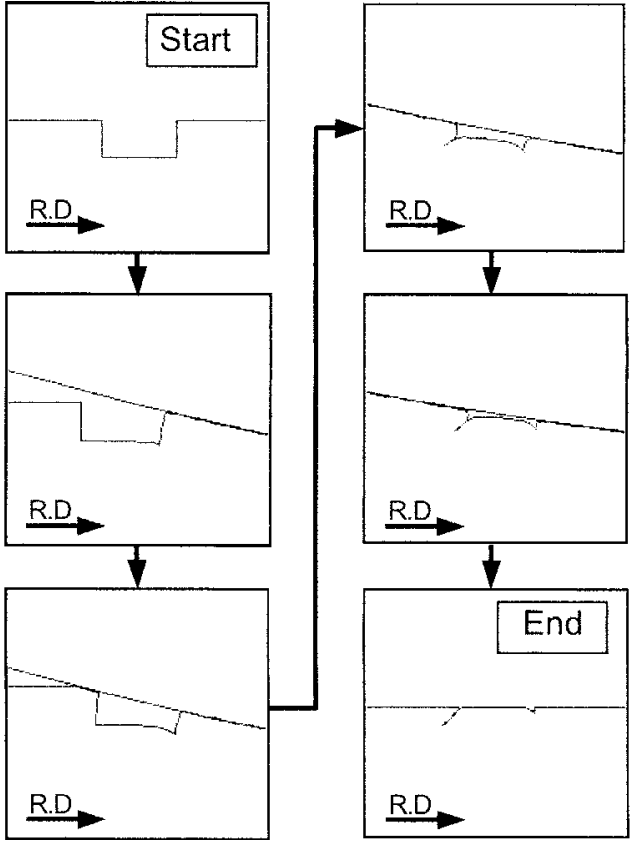

Fig.17. Example of deformation of rectangle defect ${ }^{19)}$. (thickness $t=20 \mathrm{~mm}$, rolling reduction $\varphi=30 \%, \mu=0.20$ )

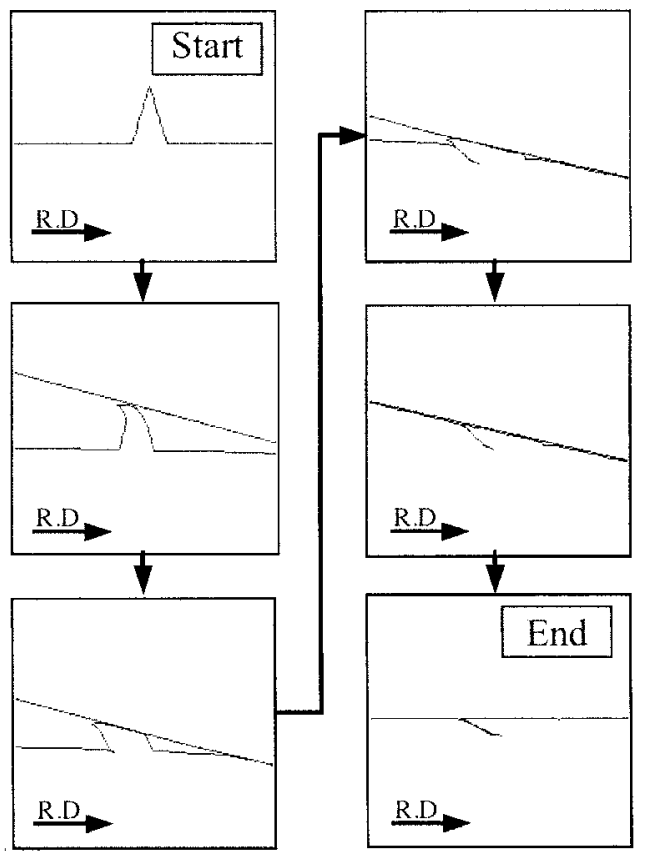

Fig.18. Example of deformation of triangle convex defect ${ }^{19)}$. (thickness $t=20 \mathrm{~mm}$, rolling reduction $\varphi=30 \%, \mu=0.20$ )

について変形解析を行った.摩擦係数は $\mu=0.20$ とした .

三角形状突起の变形過程を Fig.18 に示す.三角形の突 起はロールに接触するとロールに押しつぶさされるように 圧延方向とは逆方向に倒され，兴の後ロールにかみ込まれ る.結果的に鋼板には突起部分の後方に大きな疪跡を残す

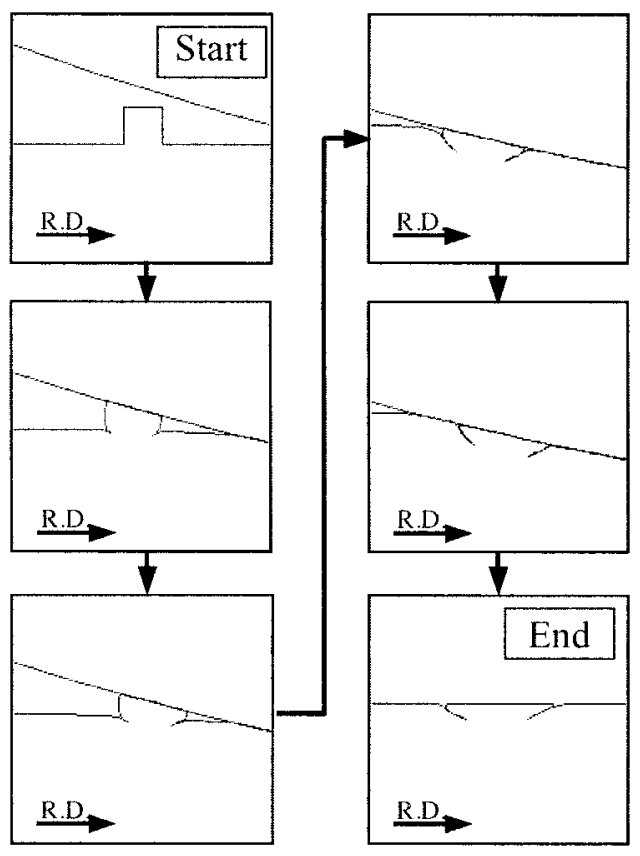

Fig.19. Example of rectangle convex defect deformation. (thickness $t=20 \mathrm{~mm}$, rolling reduction $\varphi=30 \%, \mu=0.20$ )

結果となる．しかし，疪の前方にはほとんど疪は残らな い.ロールに接触した時, 突起は摩擦により前方へ引っ張 られるが ,三角形の前方斜面の影響でロールに押しつぶさ れる効果のほうが大きくなるため, 前方への倒れこみはほ とんど起こらないと考えられる .

\section{5 矩形状凸形突起}

突出部分の長さ $\mathrm{w}_{0}$ を $1.0 \mathrm{~mm}$, 突出部分の高さ $h_{0} を 1.0$ $\mathrm{mm}$,圧下率 $30 \%$ の解析結果を Fig. 19 に示す.突起はロー ルにかみこまれるとロールにより下方に圧縮変形を受け る.弚の結果, バルジングがおこり, 弚のまま突起部は鋼 板表層に埋没していく.弚のため突起部の前方と後方に大 きな「逆八の字型」の疪が残る.三角形状の突起と異な り,突起の上面がロール表面と広く接触し前方にも倒れこ むのが確認できる .

\section{5 .まとめ}

圧延における表面疪に関する研究を概説し, $\mathrm{V}$ 字形状欠 陥, 矩形状凹形疵, 三角形突起，矩形状凸形突起に関して 形状, 圧延条件を変化させて, 弚の影響と圧延前後の疪形 状の関係を数值解析した結果を紹介した .

$\mathrm{V}$ 字形状疵に関して :

1) $V$ 字形状の疵では圧延前の $V$ 字形状から, 鋼板表面に 露出することで開く.中心角が小さい疪ほど疪の底部から 圧着を起こし閉じる。

2) 疵の変形に対しては摩擦が大きく影響する 摩擦が大き 
いほど圧延方向への傾斜が大きくなり，V字疵は閉じる傾 向にある

3) 圧下率の大きいものではV 字疵は開く傾向がある .

4) ロール径の大きい条件ほど疪は閉じる傾向がある .

凹形疵に関して :

1) 疵は圧延により前後の壁面か倒れこんだ「ハの字型」に 残る。

2) 高摩擦状態では前方の疵は減少する.

凸形疵に関して :

1) 先端が三角形状の場合, 圧延後は突起が後方に押し倒さ れることで突起後方に疪ができる．

2) 矩形状の突起の場合, 突起部は圧縮され, 突起の前後に

「逆八の字型」の疵が形成される．高摩擦状態では突起部 は前方に倒れこむことで後方の疵は減少する．

Fig.20は,結果をまとめたものである.ここでは圧延時 の疵形状の変化を模式的に考えたもので,この数值解析に より圧延後の疵形状から光の原因をある程度は推定する ことが可能であると考えられ，疵防止対策の手段となるこ とが期待できる .

従来から現象が明確でないため抜本的な対策が遅れて いた圧延疵問題に対して ここで紹介したように理論的な メスを入れることが可能になり，欠陥フリ一圧延製品製造 技術が格段に進歩するものと考える.

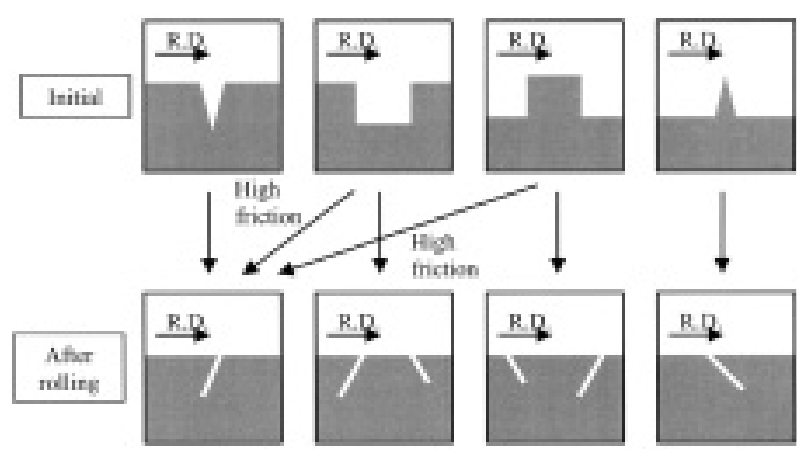

Fig.20. Relationship between initial and final shape of surface defects.
(文 献)

1) 日本金属学会·日本鉄鋼協会編:鉄鋼材料便覧 .

2) 日本鉄鋼協会編:第3版鉄鋼便覧 III (1) 圧延基礎-鋼板.

3）桝井明 梶谷英雄，小林周司，矢野幸三須田豊治，三辻 晴夫:鉄と鋼講演概要集 (II)，(1982），S360 .

4) 角南英八郎 寒河江裕:鉄と鋼講演概要集( II ), (1982), S415.

5) 小河卓, 生嶋栄次:鉄と鋼講演概要集, (1975), S55 .

6) 肥後裕一,小田桐繁, 簿田研一:日新製鋼技報, 55 (1986) ,18.

7) 井上健, 安中弘行 松本洋:材料とプロセス, 6(1993), 1167.

8) 松井利光 緒方俊治, 藤田通孝, 浅川基男:住友金属，26 (1974) ,3,324 .

9) 日本鉄鋼協会:「表面疪発生過程予測技術の開発 $」$ 研究会 報告書, (2004) .

10) 高橋德三郎:塑性と加工 ,2(1961) ,9,463 .

11) 福島傑浩:材料とプロセス,12(1999) ,331.

12) 松原行宏 蛭田敏樹, 山下道雄 北浜正法:第112回圧延 理論部会,(2000), 圧理112-1。

13) 間㴊秀里, 河野幸三, 高瀬 勝, 加藤弘之:鉄と鋼講演 概要集 ( I ), (1987) S1062.

14）宇城工:川崎製鉄技報, 16(1984) 53,46 .

$15)$ 山本章夫:鉄と鋼, 74(1988), 1028.

16) 小野田克巳, 岡部央 能美亮一,長谷登:住友金属, 20 ) 1 1968) 1 .

17) 冨永賢二, 小出正人 森田正彦,山下道雄: 材料とプロ セス $, 8(1995), 1242$.

18) 加藤健三, 斎藤好弘 森高満: 昭和53年塑性加工春季講 演会講演論文集，(1978）,197。

19) 石川孝司, 湯川伸樹, 吉田佳典, 殿畑雄飛:鉄と鋼, 89 (2003), 1142. 